\title{
Failure of luteolysis and extension of the interoestrous interval in sheep treated with the progesterone antagonist mifepristone (RU 486)
}

\author{
G. L. Morgan ${ }^{1 *}$, R. D. Geisert ${ }^{2}$ †, J. P. McCann ${ }^{3}$, F. W. Bazer ${ }^{4} t^{\prime}$ \\ T. L. Ott ${ }^{4} \S$, M. A. Mirando ${ }^{4} \ddagger$ and M. Stewart ${ }^{2}$ \\ Departments of ${ }^{1}$ Veterinary Medicine and Surgery, ${ }^{2}$ Animal Science and ${ }^{3}$ Physiological Sciences, \\ Oklahoma State University, Stillwater, OK 74078, USA; and ${ }^{4}$ Department of Animal Science, \\ University of Florida, Gainesville, FL 32611, USA
}

\begin{abstract}
The progesterone antagonist mifepristone (RU 486) was injected i.m. into ewes during the early luteal phase of the oestrous cycle to test the hypothesis that duration of uterine exposure to progesterone from the corpus luteum initiates luteolysis through the proper timing of endometrial oxytocin receptor expression and pulsatile secretion of $\mathrm{PGF}_{2 \alpha}$ coincident with release of luteal oxytocin. In Expt 1, duration of cycle, the PGF ${ }_{2 \alpha}$ metabolite 15-keto-13,14,-dihydro$\mathrm{PGF}_{2 \alpha}$ (PGFM) and oxytocin concentrations were measured in ewes treated on days 5, 6, 7 and 8 of the oestrous cycle with either 2.5 or $5.0 \mathrm{mg} \mathrm{RU} 486 \mathrm{~kg}^{-1}$ day ${ }^{-1}(n=4$ per group); control ewes $(n=6)$ were injected i.m. with $80 \%$ ethanol (diluent). In Expt 2, the presence of functional uterine oxytocin receptors was determined indirectly on day 12 of the cycle by measuring the plasma PGFM response to oxytocin challenge (20 iu, i.v.) in diluent-treated ewes $(n=3)$ and in ewes treated with $2.5 \mathrm{mg} \mathrm{RU} 486 \mathrm{~kg}^{-1}$ day ${ }^{-1}$ on days 6,7 and 8 of the oestrous cycle. Duration of the oestrous cycle of control ewes (16 \pm 1 days) was extended beyond day 24 (day $0=$ oestrus) in 10 of 11 ewes treated with RU 486 as determined by daily exposure of ewes to a ram and by measurement of progesterone concentrations in plasma in the two experiments. Luteolysis (days 14-16) in control ewes was preceded (days 12-15) by pulsatile release of PGFM in plasma and by the presence of functional endometrial oxytocin receptors that responded to oxytocin challenge (day 12) with a significant increase in plasma PGFM concentrations. RU 486 treatment prevented pulsatile PGFM release on days $12-15$ and release of $\mathrm{PGF}_{2 \alpha}$ following oxytocin challenge on day 12 but not on day 20 when oxytocin administration was repeated. The absence of pulsatile PGFM release in ewes treated with RU 486 on days 12, 13, 14 and 15 in Expt 1 was associated with different plasma oxytocin activity in treated and control ewes in that plasma oxytocin increased from days 12 to 14 in mifepristone-treated but not in control ewes. We conclude that adequate progesterone exposure during the early to mid-luteal phase of the oestrous cycle is essential for initiation of ovarian-uterine mechanisms that lead to luteolysis in ewes.
\end{abstract}

\section{Introduction}

Prostaglandin $\mathrm{F}_{2 \alpha}\left(\mathrm{PGF}_{2 \alpha}\right)$ secreted by the uterine endometrium has been identified as the luteolytic hormone in ewes (McCracken et al., 1972). Luteal oxytocin mediates the release of $\mathrm{PGF}_{2 \alpha}$ at the time of luteolysis in ewes (Sharma and Fitzpatrick, 1974; Roberts et al., 1976; Flint and Sheldrick, 1982). The pulsatile secretion of oxytocin by the corpus luteum and $\mathrm{PGF}_{2 \alpha}$ by the endometrium are temporally related, which suggests that each hormone affects secretion of the other (Swann et al., 1984; Hooper

\footnotetext{
${ }^{*}$ Reprint requests.

tCorrespondence.

$\ddagger$ Present address: Animal Science Department, Texas A\&M University, College Station, TX 77843-2471, USA

$\S$ Present address: Department of Animal Sciences, Washington State University, Pullman, WA 99164-6332, USA.

Received 13 August 1992.
}

et al., 1986). McCracken (1980) proposed that a positive feedback loop between these two hormones is involved in luteolysis.

Progesterone, together with oestradiol, regulates the increase in endometrial oxytocin receptor concentration during late dioestrus in ewes (Roberts et al., 1976; Flint et al., 1990; Vallet et al., 1990). Progesterone also stimulates synthesis of $\mathrm{PGF}_{2 a}$ by uterine epithelial cells (Silvia et al., 1991). The finding that progesterone exerts dual regulation of oxytocin receptor content and endometrial capacity for $\mathrm{PGF}_{2 \alpha}$ synthesis suggests that progesterone stimulation or priming of the endometrium is necessary for coordinated responses between the corpus luteum and endometrium at the time of luteolysis in sheep. Studies have proposed that following a period of progesterone stimulation, the endometrium becomes desensitized to the inhibitory effects of progesterone on oestrogen receptor synthesis, thus allowing oestrogen stimulation of oxytocin receptors (see Flint et al., 1990; Geisert et al., 1992). This contention is supported by 
the finding that exogenous progesterone administration during metoestrus decreases the interoestrous interval in ewes and cows (Woody et al., 1967; Moore et al., 1986; Garrett et al., 1988). These findings suggest that exposure to physiological concentration of progesterone during dioestrus programmes the endometrium to respond appropriately at the time of luteolysis.

This study examined the hypothesis that exposure to progesterone in early to mid-dioestrus regulates uterine release of $\mathrm{PGF}_{2 \alpha}$ at luteolysis in sheep. The hypothesis was tested by administering the progesterone antagonist, mifepristone, to ewes on day 5-8 of the oestrous cycle. Mifepristone (RU 486) binds with high affinity to the progesterone receptor, but renders the occupied receptor incapable of gene transcription (Rauch et al., 1985; Bailly et al., 1986). We anticipated that specific inhibition of progesterone receptor function would be associated with reduced plasma $\mathrm{PGF}_{2 \alpha^{\prime}}$, failure of luteolysis in late dioestrus and extension of the interoestrous interval.

\section{Materials and Methods}

\section{Animals}

Twenty Rambouillet-Dorset ewes, $4-6$ years old, and weighing $51-63 \mathrm{~kg}$, were used in two experiments. Oestrus was determined daily using vasectomized rams fitted with marking harnesses. The day of first marking was designated as day 0 of the oestrous cycle. Ewes were housed in an open shelter and provided with water and high quality prairie hay ad libitum.

\section{Experiment 1}

Fourteen ewes were randomly assigned to receive s.c. 2.5 $(n=4)$ or $5(n=4) \mathrm{mg} \mathrm{RU} 486 \mathrm{~kg}^{-1}$ day ${ }^{-1}$ on days $5,6,7$ and 8 of the oestrous cycle; control ewes $(n=6)$ were injected s.c. on days $5,6,7$ and 8 with $50 \mu 180 \%$ ethanol $\mathrm{kg}^{-1}$ day $^{-1}$. Mifepristone (RU 486), I1 $\beta$-(4-dimethyl-amino-phenyl)-17 $\beta$ hydroxy-17 $\alpha$-(prop-1-ynyl)-estra-4,9-dien-3-one (donated by Roussal-Uclaf, Paris), was diluted (50 $\mathrm{mg} \mathrm{ml}^{-1}$ ) in $80 \%$ ethanol.

Jugular blood $(5 \mathrm{ml})$ was collected daily $(08: 30 \mathrm{~h})$ by venepuncture for 22 days from day 0 (oestrus) of the oestrous cycle. After collection of blood samples, tubes were immediately placed in an iced water bath until they were centrifuged $(700 \mathrm{~g}$ for $5 \mathrm{~min}$ ) and recovered plasma was stored at $-20^{\circ} \mathrm{C}$ until assayed for progesterone. Ewes were checked for oestrous behaviour daily with vasectomized rams.

On day 11, polyvinyl catheters were placed in the jugular vein of four control ewes and four ewes treated with $2.5 \mathrm{mg}$ $\mathrm{RU} 486 \mathrm{~kg}^{-1}$ day $^{-1}$. From day 12 , blood samples $(5 \mathrm{ml})$ were collected via the catheter at intervals of $1 \mathrm{~h}(06: 00-18: 00 \mathrm{~h})$ on days $12,13,14$ and 15 of the oestrous cycle. After harvesting the plasma, samples were stored at $-20^{\circ} \mathrm{C}$ until assayed for PGFM and oxytocin content.

A subgroup of ewes was treated daily with either vehicle $(n=3)$ or $2.5 \mathrm{mg} \mathrm{RU} 486 \mathrm{~kg}^{-1} \mathrm{day}^{-1}(n=3)$ from day 5 to day 8 . Ewes were laparotomized on day 5 and the corpora lutea on the ovaries marked with suture. On day 15 of the oestrous cycle, ewes were hysterectomized and the ovaries dissected to confirm the presence of the original corpus luteum in the ewes treated with RU 486 and to determine whether ewes formed any new corpora lutea during the treatment period.

\section{Experiment 2}

Cyclic ewes were assigned to be treated either s.c. with $2.5 \mathrm{mg}$ RU $486 \mathrm{~kg}^{-1} \mathrm{day}^{-1}(n=3)$ or $80 \%$ ethanol $(n=3)$ on days 6,7 and 8 of the oestrous cycle. Ewes were checked for oestrous behaviour daily. Plasma was obtained from blood collected daily (08:30) by jugular venepuncture throughout the experiment. Blood samples were collected, centrifuged $\left(700 \mathrm{~g}\right.$ for $5 \mathrm{~min}$ ) and plasma was stored at $-20^{\circ} \mathrm{C}$. Ewes were catheterized on day 11 as described in Expt 1. On day 12, ewes were treated sequentially with an i.v. injection of saline $(1 \mathrm{ml}$ $0.9 \% \mathrm{NaCl}$ ) and $20 \mathrm{iu}$ oxytocin ( $1 \mathrm{ml}$ ), which was injected $90 \mathrm{~min}$ after the saline injection. Blood samples $(4 \mathrm{ml})$ were obtained via the jugular catheter $10 \mathrm{~min}$ before and $10,20,30$, $40,50,60$ and $70 \mathrm{~min}$ after each injection. The sequential saline-oxytocin protocol was repeated on day 20 of the treatment cycle if control or RU 486-treated ewes had not been detected to be at oestrus. Plasma samples were assayed for PGFM content after saline and oxytocin treatment.

\section{Hormone analyses}

Plasma concentrations of progesterone and PGFM were quantified by enzymatic-colorimetric assay (Cambridge Life Sciences, Cambridge, UK) and radioimmunoassay (Vallet et al., 1988), respectively. Sensitivity of the progesterone enzymaticcolorimetric assay was $0.5 \mathrm{ng} \mathrm{ml}^{-1}$ with intra- and interassay coefficients of variation of 10 and $25 \%$, respectively. Analysis of plasma samples containing $0.5,1.2,4.5,6.7$ and $8.5 \mathrm{ng}$ progesterone $\mathrm{ml}^{-1}$ with the enzymatic-colorimetric assay recovered 0.5 , $1.1,4.7,6.2$ and $9.2 \mathrm{ng}$ progesterone $\mathrm{ml}^{-1}$, respectively $(Y=$ $0.014+1.145 X_{;} R^{2}=0.89$ ). The antiserum used crossreacted $66 \%$ with $11 \alpha$-hydroxy-progesterone and $16 \%$ with 5 -pregnane$3 \beta$-ol-20-one but $<5 \%$ with $5 \beta$-pregnan-3, 20-dione, $5 \alpha$ pregnane-3, 20-dione, oestradiol, oestrone, testosterone and corticosterone. The PGFM radioimmunoassay had a sensitivity of $5 \mathrm{pg} \mathrm{ml}^{-1}$ with intra- and interassay coefficients of variation of 7.5 and $5.6 \%$, respectively. Concentrations of oxytocin in unextracted plasma were determined by radioimmunoassay using reagents and procedures described by Gorewit (1979). Anti-oxytocin antisera was purchased from Calbiochem Inc (La Jolla, CA) and [ $\left.{ }^{125} \mathrm{I}\right]$-labelled oxytocin was purchased from Du Pont (Wilmington, DE). The oxytocin radioimmunoassay had a sensitivity of $3 \mathrm{pg} \mathrm{ml}^{-1}$ and intra- and interassay coefficients of variation were $3.6 \%$ and $11.8 \%$, respectively. Control ewes and ewes treated with RU 486 in Expt I were paired and all samples for each pair were included in the same assay for quantification of either PGFM or oxytocin concentration.

\section{Statistical analysis}

Differences in mean daily concentrations of progesterone, PGFM and oxytocin between control and RU 486-treated ewes during window bleeds on days 12-15 were evaluated by the repeated measures method of Gill (1979). Student's unpaired $t$ test was used to determine whether the mean number of 
PGFM pulses in plasma during window bleeds differed between control and RU 486-treated sheep. A pulse of PGFM in each ewe was defined as a peak in which one value within the peak exceeded the overall basal value plus one standard deviation. Effect of RU 486 and day of oestrous cycle (days $12-$ 14) on integrated PGFM and oxytocin response area during the window bleeds were tested by $2 \times 3$ split plot analysis of variance and Duncan's new multiple range test (Steele and Torrie, 1980). Owing to the small number of ewes in Expt 2, the effect of oxytocin treatment on plasma PGFM response on days 12 and 20 of the oestrous cycle was examined in each ewe by comparing PGFM concentrations after oxytocin treatment with the upper $95 \%$ confidence interval for the mean value obtained during saline treatment (Steele and Torrie, 1980).

\section{Results}

\section{Experiment 1}

No differences were noted in the variables measured between ewes treated with 2.5 or $5 \mathrm{mg}$ RU $486 \mathrm{~kg}^{-1}$ day $^{-1}$. Data were therefore pooled to provide eight ewes treated with RU 486. Analysis of plasma progesterone concentrations indicated that duration of the oestrous cycle in the control ewes ranged from 16 to 18 days. This was corroborated by the paint markings of the vasectomized harnessed rams. Concentrations of progesterone in plasma were maintained above $2 \mathrm{ng} \mathrm{ml}^{-1}$ to day 22 $(P<0.01)$ in seven of eight ewes treated with RU 486 in contrast to the decline of plasma progesterone on days 16-18 of the oestrous cycle in control ewes. Concentration of progesterone in the plasma of ewes treated with $5 \mathrm{mg} R U 486 \mathrm{~kg}^{-1}$ day $^{-1}$ remained above $4 \mathrm{ng} \mathrm{ml}^{-1}$ throughout the sampling period to day 22 (Fig. 1). Luteolysis occurred in only one RU 486-treated ( $2.5 \mathrm{mg} \mathrm{kg}^{-1}$ day $\left.^{-1}\right)$ ewe during the sampling period. Concentrations of progesterone in plasma were greater $(P<0.025)$ in RU 486-treated than in control ewes on days 16 , 18,20 and 22 of the oestrous cycle. The exact interoestrous interval in RU 486-treated ewes with extended cycles was not determined because the experiment was terminated on day 24 . These ewes had not been marked by rams by day 24 . An additional group of ewes were laparotomized on day 5 and corpus luteum marked with suture to confirm that the original corpus luteum was maintained and that extension of the interoestrous interval in RU 486-treated ewes was not the result of ewes ovulating or luteinization of follicles. Two of three RU 486-treated ewes had maintained their corpus luteum on day 15 compared with none of the three control ewes. No accessory corpora lutea or luteinized follicles were observed in the RU 486-treated ewes.

The plasma profile of PGFM on days $12,13,14$ and 15 indicated pulsatile secretion of PGFM in control, but not in RU 486treated ewes (Fig. 2). Catheters from two RU 486-treated ewes failed to remain patent and no blood samples were obtained on day 15. Only a single pulse of PGFM was detected in each of two RU 486-treated ewes during the four-day intensive bleeding period. Within the limits of our PGFM assay, no PGFM pulses were detected in the other two RU 486-treated ewes intensively sampled on days $12-15$. In contrast, numerous

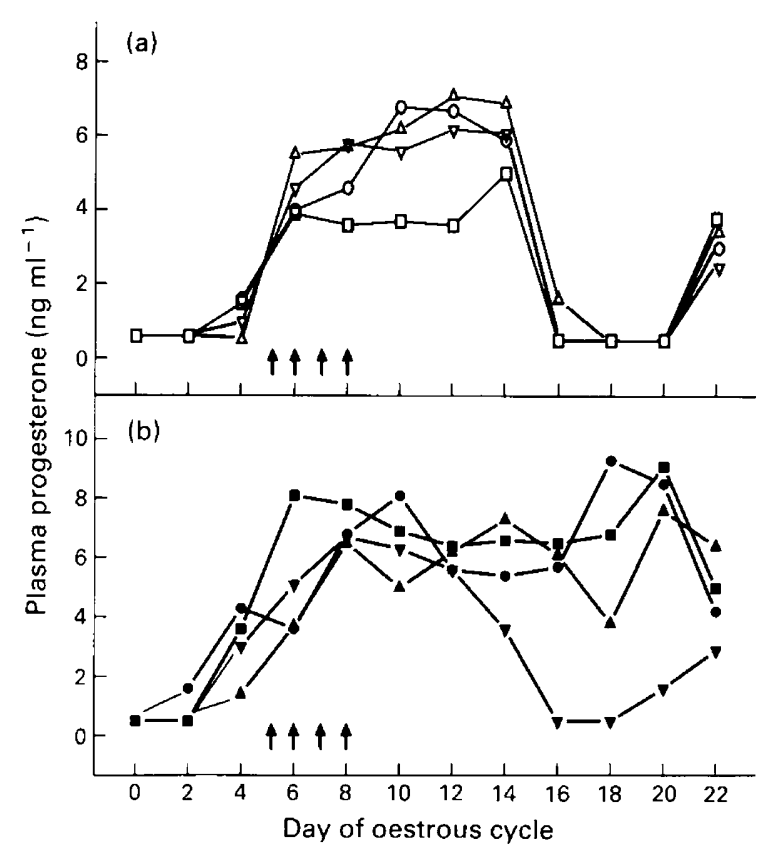

Fig. 1. Concentrations of progesterone in plasma of (a) four representative vehicle-treated and (b) three representative RU 486-treated ewes that exhibited extended oestrous cycles and one RU 486-treated ewe with a normal cycle length. $2.5 \mathrm{mg} \mathrm{RU} 486 \mathrm{~kg}^{-1}$ day ${ }^{-1}$ was administered on days 5, 6, 7 and 8 of the oestrous cycle.

pulses of PGFM were detected in the four control ewes during the intensive sampling period. Pulses of PGFM were evident in control ewes as early as days 12 and 13 of the oestrous cycle which was before concentrations of progesterone in plasma began to decline coincident with luteolysis. The integrated plasma concentration of PGFM tended to be greater $(P<0.09)$ in control $\left(178 \pm 43 \mathrm{pg} \mathrm{ml}^{-1} \mathrm{~h}^{-1}\right)$ than in RU 486-treated $\left(83 \pm 34 \mathrm{pg} \mathrm{ml}^{-\overline{1}} \mathrm{~h}^{-1}\right)$ ewes on days $12-14$ of the oestrous cycle.

The pulsatile pattern of plasma oxytocin in jugular blood samples over the $12 \mathrm{~h}$ sampling window on days $12-15$ was similar $(P<0.10)$ in control and RU 486-treated ewes (Fig. 3). However, there was a trend for an interaction $(P<0.07)$ between RU 486 treatment and day of the cycle on the integrated plasma oxytocin concentration. Plasma oxytocin increased during the sampling period in RU 486-treated but not in control ewes after day 12 of the cycle. These results suggest that oxytocin stimulation of the uterus at the expected time of luteolysis was more than adequate in RU 486-treated ewes, provided that plasma oxytocin reflects the degree of oxytocin stimulation at the cellular level in the uterus.

\section{Experiment 2}

Administration of $20 \mathrm{iu}$ oxytocin on day 12 elicited an increase $(P<0.05)$ in plasma PGFM in control ewes, but no PGFM response to oxytocin was detected in RU 486-treated ewes (Fig. 4). An increase $(P<0.05)$ in plasma PGFM was detected, however, when oxytocin challenge was repeated on 


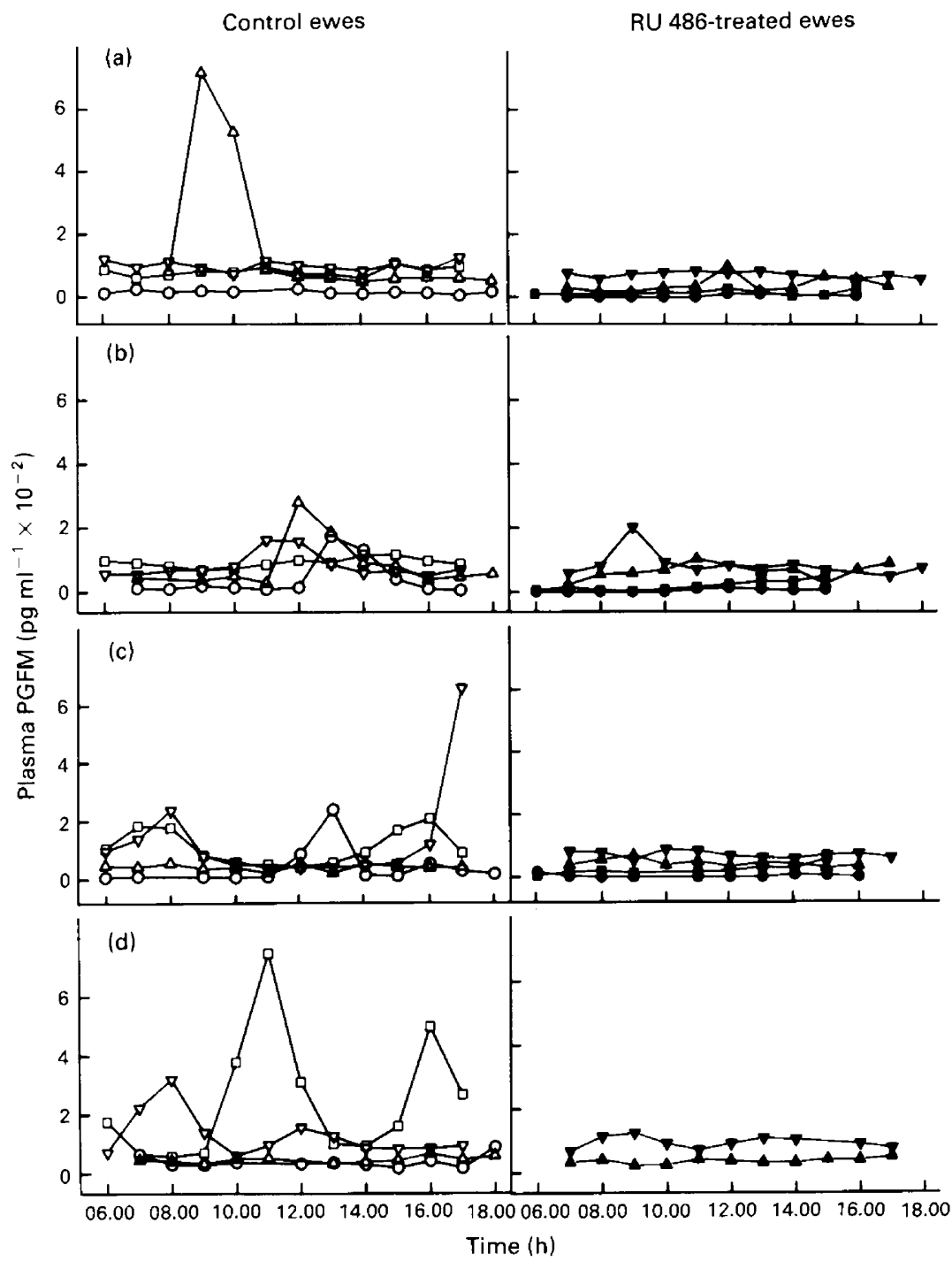

Fig. 2. Concentration of PGFM in plasma collected every hour for $12 \mathrm{~h}$ on days (a) 12 , (b) 13 , (c) 14 and (d) 15 of the oestrous cycle in ewes treated with vehicle $(n=4)$ or $2.5 \mathrm{mg}$ RU $486 \mathrm{~kg}^{-1}$ day $^{-1}(n=4)$ on days $5,6,7$ and 8 of the oestrous cycle. Frequent samples were not obtained from two RU 486 ewes on day 15 owing to loss of catheters.

day 20 in the three RU 486-treated ewes in which luteolysis had not occurred.

\section{Discussion}

Administration of the progesterone antagonist RU 486 to cyclic ewes in the early to mid-luteal phase of the oestrous cycle resulted in failure of luteolysis and preservation of a functional corpus luteum to at least day 24 after oestrus. Failure of luteolysis resulted from the absence of adequate $\mathrm{PGF}_{2 \alpha}$ secretion from the endometrium as demonstrated by the absence of spontaneous PGFM pulses in plasma and uterine refractoriness to oxytocin stimulation in ewes treated with RU 486 during the period of normal luteolysis in sheep.

Oxytocin, perhaps from the corpus luteum, appears to initiate release of $\mathrm{PGF}_{2 \alpha}$ from the endometrium at luteolysis in ewes (see Silvia et al., 1991). For this to occur, oxytocin receptors must be present in the endometrium. Progesterone and oestrogen play a role in regulating development and responsiveness of the uterine oxytocin receptor (Vallet et al., 1990; Lau et al., 1992). Oxytocin receptors are present in the uterine endometrium at the time in the oestrous cycle when $\mathrm{PGF}_{2 \alpha}$ synthesis and its release by the uterus in response to oxytocin stimulation are at a peak (Vallet et al., 1990). Furthermore, Vallet et al. (1990) indicated that administration of progesterone alone to ovariectomized ewes for 12 days stimulated both an increase in endometrial oxytocin receptor concentration and $\mathrm{PGF}_{2 \alpha}$ responsiveness to oxytocin challenge. However, there are more endometrial oestrogen receptors during late dioestrus than at earlier stages (Findlay et al., 1982; Cherny et al., 1991) and oestrogen is essential for stimulating luteolysis in ewes (Zhang et al., 1991). These results suggest that progesterone plays an important role in regulating the timing of 


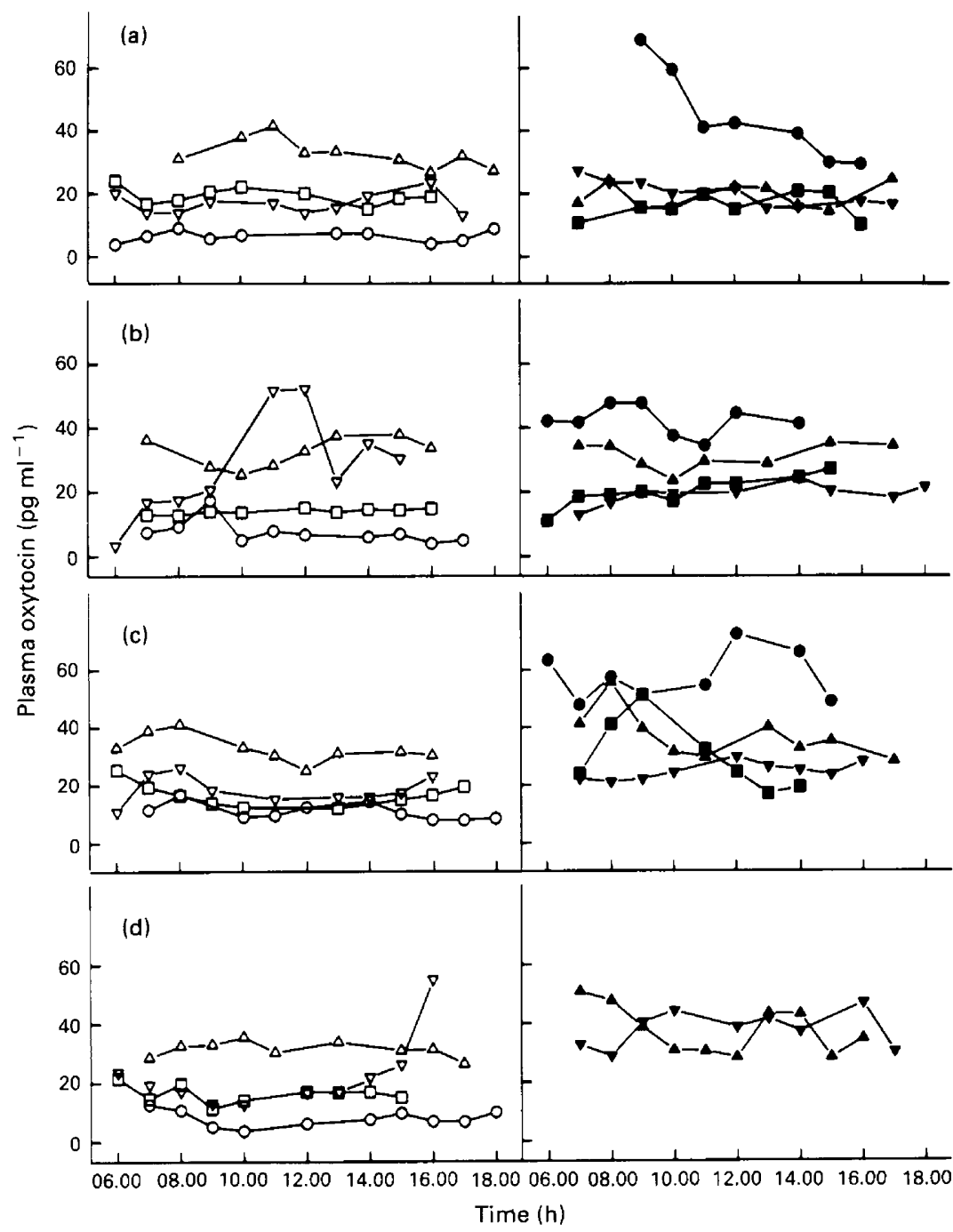

Fig. 3. Concentration of oxytocin in plasma collected every hour for $12 \mathrm{~h}$ on day (a) 12 , (b) 13 , (c) 14 and (d) 15 of the oestrous cycle in ewes treated with vehicle $(n=4)$ or $2.5 \mathrm{mg} \mathrm{RU} 486 \mathrm{~kg}^{-1}$ day $^{-1}(n=4)$ on days $5,6,7$ and 8 of the oestrous cycle. The same symbols are used for each ewe in Figs 2 and 3. Frequent samples were not obtained from two RU 486 ewes on day 15 owing to loss of catheters.

luteolysis. It has been clearly shown in cattle (Garrett et al., 1988) and sheep (Ottobre et al., 1980) that administration of progesterone immediately after oestrus advances the release of $\mathrm{PGF}_{2 \alpha}$ and shortens the interoestrous interval.

The mechanism(s) responsible for regulation of the luteolytic process in sheep is not completely known. However, it has been suggested that downregulation of the uterine epithelial progesterone receptor by exposure to progesterone during dioestrus is a key event in progesterone timing of luteolysis in sheep as well as in other species (see Bazer, 1992). Specifically, homologous downregulation of uterine epithelial progesterone receptors allowed the uterine expression of oxytocin receptors, a necessary prerequisite for oxytocin stimulation of uterine $\mathrm{PGF}_{2 \alpha}$ secretion during luteolysis. This contention is supported by immunohistochemical studies that showed an abrupt decrease in staining intensity for progesterone receptor in uterine epithelium beginning on day 11 of the ovine oestrous cycle (R. D.
Geisert, T. L. Ott and F. W. Bazer, unpublished results). It has previously been reported that uterine responsiveness to oxytocin in oestrogen-treated ewes required progesterone priming for 8-10 days (McCracken et al., 1984). Although the withdrawal of progesterone is necessary for a large increase in oxytocin receptor synthesis (Lau et al., 1992), endometrial sensitivity to oxytocin-stimulated release of $\mathrm{PGF}_{2 \alpha}$ increases before the initial decline in serum progesterone. Progesterone initially inhibits the formation of endometrial oxytocin receptors early in the oestrous cycle of progesterone-treated ovariectomized ewes (Vallet et al., 1990; Lau et al., 1992). However, oxytocin receptors increase on day 14 of the cycle and continue to increase even in ewes treated with progesterone to day 30 (Vallet and Lamming, 1991; Fairclough and Lau, 1992). For complete and coordinated luteolysis, the uterine endometrium must experience progesterone stimulation for a finite period and this precedes a definite timing of progesterone receptor loss 


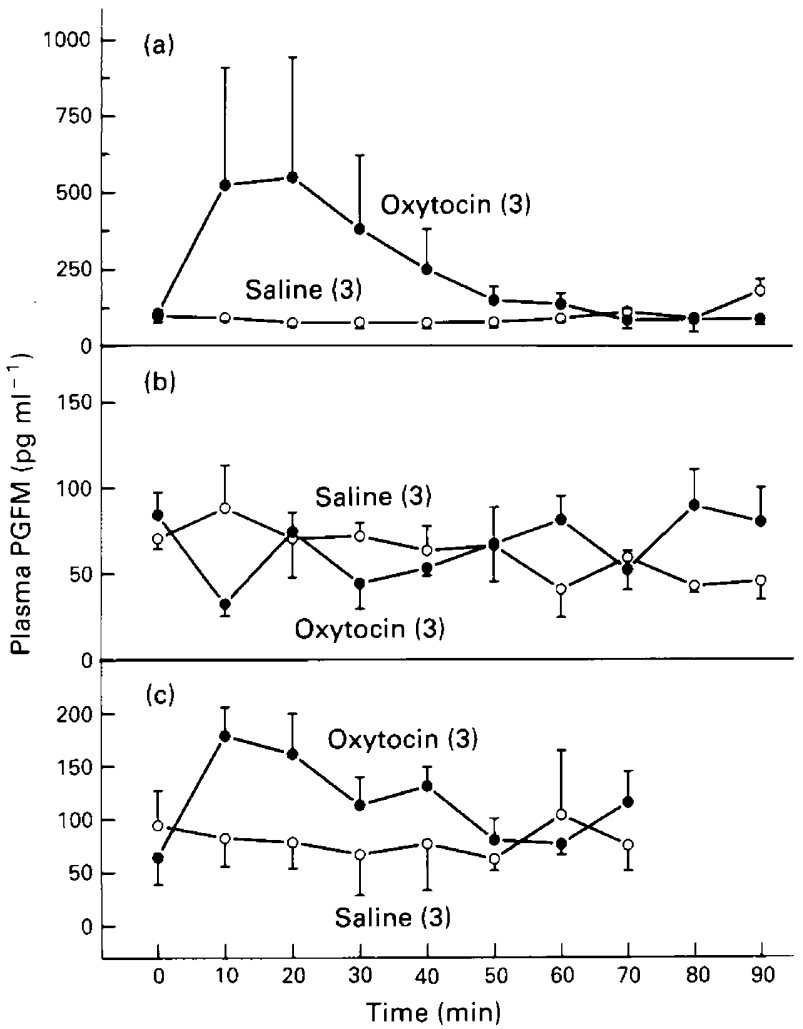

Fig. 4. Mean ( \pm SEM) concentrations of PGFM in plasma of (a) control ewes injected i.v. with saline followed by 20 iu oxytocin on day 12 , and RU 486-treated ewes injected with saline followed by 20 iu oxytocin on day (b) 12 and (c) 20 of the oestrous cycle. Ewes were treated s.c. with diluent (control, $n=3$ ) or $2.5 \mathrm{mg} \mathrm{RU} 486 \mathrm{~kg}^{-1}$ day ${ }^{-1}(n=3)$ on days 6,7 and 8 of the oestrous cycle. Oxytocin increased plasma PGFM in control ewes on day $12(P<0.05)$ and in RU 486-treated ewes on day $20(P<0.05)$, but not on day 12 .

in the uterine epithelium. Thus, the duration of progesterone exposure determines the timing of epithelial progesterone receptor loss that is associated with physiological change in uterine function as reported in this study and by McCracken et al. (1984) and Ayad et al. (1991).

Results of the present study clearly demonstrated that if progesterone receptor function is inhibited, delaying the effect of progesterone on downregulating its receptor, luteolysis at the expected time in the oestrous cycle of the ewe is prevented. We did not determine whether failure of luteolysis resulted from inadequate endometrial synthesis of $\mathrm{PGF}_{2 \alpha^{\prime}}$ blockage of endometrial oestrogen receptor or interference with synthesis of the oxytocin receptors for pulsatile $\mathrm{PGF}_{2 \alpha}$ release. Present data indicate that the functional integrity of the ovarian-endometrial luteolytic endocrine axis is altered by delaying progesteronestimulated effects on endometrial development and function. A delay in endometrial prostaglandin synthesis, inhibition of endometrial oestrogen receptor or the presence of few epithelial oxytocin receptors could have impaired the luteolytic process in ewes the uteri of which were unresponsive to an apparently normal concentration of oxytocin in plasma. In support of this hypothesis, RU 486 treatment rendered the uterus unresponsive to a challenge with oxytocin on day 12 of the oestrous cycle as indicated by the failure to release $\mathrm{PGF}_{2 a}$. However, those ewes responded with PGFM release when oxytocin was administered on day 20,13 days after the last RU 486 treatment, which suggests that a sufficient period of progesterone stimulation of the uterus had elapsed for re-establishment of uterine responsiveness to oxytocin. Failure of luteolysis to occur on day 22 in RU 486-treated ewes, despite the re-establishment of uterine responsiveness to oxytocin, may result from inadequate luteal oxytocin release from an aged corpus luteum as indicated by Lamsa et al. (1989). Extension of the interoestrous interval similar to that in the present study was achieved by exposing the uterus to an oxytocin receptor antagonist (CAP 449) during the late luteal phase of the ovine oestrous cycle (Jenkin, 1992).

Results of the present study have demonstrated that inhibition of the uterine progesterone receptor early in the oestrous cycle of the ewe interferes with the normal timing of luteolysis. Failure of luteolysis can be explained by the fact that the window of uterine sensitivity for luteolysis was shifted or delayed by RU 486 treatment. Although adequate oxytocin release from the corpus luteum may have occurred, the functional integrity of the endometrium was altered so that timing of ovarian oxytocin release did not correspond to responsiveness of the endometrium to release $\mathrm{PGF}_{2 a}$. Future studies to determine uterine epithelial oxytocin and progesterone receptor concentrations as well as endometrial $\mathrm{PGF}_{2 \alpha}$ synthesis and oxytocin content of the corpus luteum will further explain the mechanism by which progesterone receptor inhibition results in extension of the luteal phase.

This research was supported in part by Oklahoma Agriculture Experiment Station, Grant 2-1-11400 and OKLO2058; this manuscript is published as Journal No. 6401 of the Agriculture Experiment Station, Oklahoma State University, Stillwater, Oklahoma.

\section{References}

Ayad VJ, Guldenaar SEF and Wathes DC (1991) Characterization and localization of endometrial oxytocin receptors in the uterus and oviduct of the nonpregnant ewe using an iodinated receptor antagonist Joumal of Endocrinology 128 187-195

Bailly A, LePlage C, Rauch M and Milgram E (1986) Sequence specific DNA binding of the progesterone receptor to the uteroglobin gene: effects of hormone, antihormone and receptor phosphorylation EMBO journal 5 $3235-3241$

Bazar FW (1992) Mediators of maternal recognition of pregnancy in mammals Proceedings of the Society for Experimental Biology and Medicine 199 373--384

Cherny RA, Salamonsen LA and Findlay JK (1991) Immunocytochemical localization of oestrogen receptors in the endometrium of the ewe Reproduction Fertility and Development 3 321-331

Fairclough RJ and Lau TM (1992) Hormonal control of uterine oxytocin receptor levels in the ewe Reproduction, Fertility and Development 4 313-320

Findlay JK, Clarke IJ, Swaney J, Colvin N and Doughton B (1982) Oestrogen receptors and protein synthesis in caruncular and intercaruncular endometrium of sheep before implantation Journal of Reproduction and Fertility 64 329-339

Flint APF and Sheldrick EL (1982) Ovarian secretion of oxytocin is stimulated by prostaglandin Nature $297587-588$

Flint APF, Sheldrick EL, McCann TJ and Jones DSC (1990) Luteal oxytocin: characteristics and control of synchronous episodes of oxytocin and PGF Domestic Animal Endocrinology 7 3-20

Garrett JE, Geisert RD, Zavy MT and Morgan GL (1988) Effect of exogenous progesterone on cycle length, embryonic development and maintenance of pregnancy in the bovine Journal of Reproduction and Fertility 84 437-446

Geisert RD, Short EC and Zavy MT (1992) Maternal recognition of pregnancy Animal Reproduction Science 28 287-298 
Gill JL (1979) Combined significance of nonindependent tests for repeated measurements Journal of Animal Science 48 363-366

Gorewit RC (1979) Method for determining oxytocin concentrations in unextracted sera, characterization in lactating cattle (40394) Proceedings of the Society for Experimental Biology and Medicine 160 80-87

Hooper SB, Watkins WV and Thorburn GD (1986) Oxytocin, oxytocin-associated neurophysin and prostaglandin $\mathrm{F}_{2 \alpha}$ concentrations in the utero-ovarian vein of pregnant and non-pregnant sheep Endocrinology 119 2590-2597

Jenkin $G$ (1992) The interaction between oxytocin and prostaglandin $F_{2 a}$ during luteal regression and early pregnancy in sheep Reproduction, Fertility and Development 4 321-328

Lamsa JC, Kot SJ, Eldering JA, Nay MG and McCracken JA (1989) Prostaglandin $F_{2 \alpha}$ stimulated release of ovarian oxytocin in sheep in vivo: threshold and dose dependency Biology of Reproduction 40 1215-1223

Lau TM, Gow CB and Fairclough RJ (1992) Differential effects of progesterone treatment on the oxytocin-induced prostaglandin $\mathrm{F}_{2 \alpha}$ response and the levels of endometrial oxytocin receptors in ovariectomized ewes Biology of Reproduction 46 17-22

McCracken JA (1980) Hormone receptor control of prostaglandin $F_{2 a}$ secretion by the ovine uterus Advances in Prostaglandins and Thromboxane Research 8 $1329-1344$

McCracken JA, Carlson JC, Glew ME, Goding JR, Baird DT, Green K and Samuelsson B (1972) Prostaglandin $\mathrm{F}_{2 a}$ identified as the luteolytic hormone in the sheep Nature 238 129-134

McCracken JA, Schramm W and Okulicz WL (1984) Hormone receptor control of pulsatile secretion of $\mathrm{PGF}_{2 \alpha}$ from ovine uterus during luteolysis and its abrogation in early pregnancy Animal Reproduction Science 7 31-55

Moore LG, Choy VJ, Elliot RL and Watkins WB (1986) Evidence for the pulsatile release of $\mathrm{PGF}_{2 \mathrm{u}}$ inducing the release of ovarian oxytocin during luteolysis in the ewe Joumal of Reproduction and Fertility 76 159-166

Ottobre JS, Lewis GS, Thayne WV and Inskeep EK (1980) Mechanisms by which progesterone shortens the estrous cycle of the ewe Biology of Reproduction $\mathbf{2 3}$ 1046-1053
Rauch M, Loosfelt H, Philibert D and Milgram E (1985) Mechanism of action of an antiprogesterone, RU-486, in the rabbit endometrium. Effects of RU-486 on the progesterone receptor and on the expression of the uteroglobin gene European Joumal of Biochemistry 148 213-218

Roberts JS, McCracken JA, Gavagan JE and Soloff MW (1976) Oxytocin stimulated release of prostaglandin $F_{2 a}$ from ovine endometrium in vitro: correlation with oestrous cycle and oxytocin receptor binding Endocrinology 99 1107-1114

Sharma SC and Fitzpatrick RJ (1974) Effect of oestradiol-17 $\beta$ and oxytocin treatment on $\mathrm{PGF}_{2 \mathrm{a}}$ release in the anoestrus ewe Prostaglandins 6 97-105

Silvia WJ, Lewis GS, McCracken JA, Thatcher WW and Wilson I, Jr (1991) Hormonal regulation of uterine secretion of prostaglandin $\mathrm{F}_{2 a}$ during luteolysis in ruminants Biology of Reproduction 45 655-663

Steele RGD and Torrie JH (1980) Principles and Procedures of Statistics pp 87-91. McGraw-Hill, New York

Swann RW, O'Shaughnessey PJ, Birkett SD, Wathes DC, Porter DG and Pickering BT (1984) Biosynthesis of oxytocin in the corpus luteum FEBS Letters 174 262-266

Vallet JL and Lamming GE (1991) Ovine conceptus secretory proteins and bovine interferon- $\alpha_{1}-1$ decrease endometrial oxytocin receptor concentrations in cyclic and progesterone treated ovariectomized ewes. Journal of Endocrinology $131475-482$

Vallet JL, Bazer FW, Fliss MFV and Thatcher WW (1988) The effect of ovine conceptus secretory protein-one on interestrus interval and plasma concentrations of prostaglandins $\mathrm{F}_{2 \alpha}$ E and 13,14-dihydro-15-keto-prostaglandin $\mathrm{F}_{2 a}$ in cyclic ewes Journal of Reproduction and Fertility 84 493-504

Vallet JL, Lamming GE and Batten M (1990) Control of endometrial oxytocin receptor and uterine response to oxytocin by progesterone and oestradiol in the ewe Journal of Reproduction and Fertility $90625-634$

Woody CO, First NL and Pope AL (1967) Effect of exogenous progesterone on estrous cycle length Ioumal of Animal Science 26 139-141

Zhang J, Weston PG and Hixon JE (1991) Influence of estradiol on the secretion of oxytocin and prostglandin $F_{2 a}$ during luteolysis in the ewe Biology of Reproduction 45 395-403 